\title{
Prawo i psychologia w ochronie znaku towarowego na rynku konkurencyjnym
}

\author{
Law and psychology in the trademark protection \\ on a competitive market
}

\begin{abstract}
Na gospodarczym rynku konkurencyjnym duże znaczenie ma ochrona znaku towarowego. Ta ochrona wynika z tego, że pojawiają się firmy, które w celu wzrostu sprzedaży swoich produktów korzystają z wypracowanej wartości marki oryginalnej poprzez jej naśladowanie $\mathrm{w}$ warstwie werbalnej lub graficznej. W takim celu stosowane są także negatywne reklamy porównawcze. Prawo reguluje ochronę znaków towarowych, wskazując na podobieństwo jako kluczowy element konieczny dla powstania niebezpieczeństwa wprowadzenia w błąd co do pochodzenia towarów i usług. Dokładnie określa także warunki stosowania reklamry porównawczej. Jednak ocena podobieństwa z perspektywy psychologicznej różni się od tej oceny, która została wypracowana w prawie. W artykule na kilku przykładach badań empirycznych wykonanych w ramach ekspertyz sądowych pokazano sposób doświadczania podobieństwa przez konsumentów między znakami towarowymi. Przedstawione badania wskazują na możliwość zintegrowania podejścia prawnego i psychologicznego w ocenie podobieństwa $\mathrm{w}$ behawioralnym podejściu do prawa analogicznym do ekonomii behawioralnej respektującej ludzkie wybory.
\end{abstract}

\section{Stowa kluczowe}

znak towarowy, reklama negatywna, podobieństwo marek, nieuczciwa konkurencja

Trademarks' protection plays an essential role in the economic competitive market. This protection results from the fact that there are companies that launch new products and in order to increase sales they benefit from the value of an original brand by imitating verbal or graphic forms of the brand. Negative comparative advertising is also used for this purpose. Trademark law regulates precisely the protection of trademarks, pointing at similarity as a key element in creating a misleading situation about the origin of goods and services. Moreover, it also defines conditions in which comparative advertising may be used in order to protect consumers from misleading practices However, evaluation of similarity from a psychological perspective differs from the concept that has been developed within the legal system. Several examples of empirical studies conducted as a part of forensic examinations have revealed how consumers experienced the similarity between trademarks. The presented research shows a possibility of how to integrate legal and psychological approaches in similarity evaluation within the legal-behavioral framework as it is commonly seen in behavioral economics, which respect people's choices.

\section{Keywords}

trademark, negative advertising, brand similarity, unfair competition 


\section{Bibliografia}

Falkowski, A. (2001). Spostrzeganie jako mechanizm tworzenia doświadczenia za pomocą zmysłów. W: J. Strelau (red.), Psychologia: Podręcznik akademicki (t. 2, s. 26-55). Gdańsk: Gdańskie Wydawnictwo Psychologiczne.

Falkowski, A. (2003a). Decyzja, analogia i wiedza: podejście konstruktywistyczne. W: Z. Piskorz i T. Zaleśkiewicz (red), Psychologia umystu (s. 114-130). Gdańsk: Gdańskie Wydawnictwo Psychologiczne.

Falkowski, A. (2003b). Opinia na temat niebezpieczeństwa wprowadzenia w bład co do pochodzenia programu komputerowego oznaczonego znakiem towarowym „WinTel”, na podstawie badania podobieństwa znaku „WinTel” do znaku „Intel” należacego do firmy „Intel Corporation” ( uwzględnieniem fonetyki obu znaków i znaczenia stów „WinTel” i „Intel”). Ekspertyza dla Sądu Gospodarczego w Poznaniu.

Falkowski, A. (2010). Opinia na temat niebezpieczeństwa wprowadzenia w błąd co do pochodzenia środków czyszczących firmy Gold Drop na podstawie po-dobieństwa ich opakowań do opakowań środków czyszczacych „Vanish” firmy Reckitt Benckiser. Ekspertyza dla firmy Reckitt Benckiser.

Falkowski, A. (2011). Wplyw kampanii reklamowej „ORYGINALNY SMAK W NOWEJ PUSZCE” napoju energetyzującego „Black” Sp. z o.o. FoodCare, na postrzeganie konkurencyjnego napoju „Tiger”. Ekspertyza dla Firmy MWS Maspex.

Falkowski, A. (2012). Poznawcze teorie podobieństwa w kształtowaniu wizerunku marki gospodarczej i politycznej. W: A. Falkowski i T. Zaleśkiewicz (red.), Psychologia poznawcza w praktyce: Ekonomia, biznes, polityka (s. 261-332). Warszawa: Wydawnictwo Naukowe PWN.

Falkowski, A., Olszewska, J. i Ulatowska, J. (2015). Are look-alikes confusing? The application of the DRM paradigm to test consumer confusion in counterfeit cases. Marketing Letters, 26, 461-471. https://doi.org/10.1007/s11002-014-9279-0

Falkowski, A., Sidoruk-Błach, M., Bartosiewicz, Z. i Olszewska, J. M. (2018). Asymmetry in Similarity Formation: Extension of Similarity Theory to Open Sets of Features. American Journal of Psychology, 131(2), 151-159. https://doi.org/10.5406/amerjpsyc.131.2.0151

Falkowski, A., Szymański, M. i Woźnica, A. (2009). Deprecjacja marki w negatywnej reklamie porównawczej. Marketing i Rynek, $16(1), 15-21$.

Greenspan, A. (2008). Era zawirowań. Warszawa: Warszawskie Wydawnictwo Literackie, MUZA SA.

Jolls, C., Sunstein, C. R. i Thaler, R. (1998). A Behavioral Approach to Law and Economics. Stanford Law Review, 50, $1471-550$.

Kahneman, D. (2012). Pułapki myślenia. Poznań: Media Rodzina.

Kaid, L. L. (1997). Effects of television spots on images of Dole and Clinton. American Behavioral Scientist, 40(8), $1085-1094$. https://doi.org/10.1177/0002764297040008009

Keller, K. L. (2013). Strategic Brand Management. Building, Measuring and Managing Brand Equity. New Jersey: Prentice Hall.

Kleine, R. E. i Kernan, J. B. (1988). Measuring the Meaning of Consumption Object's: An Empirical Investigation. Advances in Consumer Research, 15, 498-504.

Krąpiec, M. A., Kamiński, S., Zdybicka, Z. i Jaroszyński, P. (1992). Wprowadzenie do filozofii. Lublin: Redakcja Wydawnictw KUL.

Maruszewski, T. (2001). Psychologia poznania. Gdańsk: Gdańskie Wydawnictwo Psychologiczne.

Nowińska, E., Promińska, U. i Szczepanowska-Kozłowska, K. (2015). Własność przemysłowa i jej ochrona. Warszawa: LexisNexis.

Roediger, H. L. III i McDermott K. B. (1995). Creating False Memories: Remembering Words Not Presented in Lists. Journal of Experimental Psychology: Learning, Memory and Cognition, 21, 803-814.

Skubisz, R. (2017). System Prawa Prywatnego, Prawo Własności Przemysłowej, (tom 14 B). Warszawa: CH Beck, Instytut Nauk Prawnych PAN.

Thaler, R. H. (2015). Misbehaving: The Making of Behavioral Economics. New York: W. W. Norton and Company.

Tversky, A. (1977). Features of similarity. Psychological Review, 84(4), 327-352. http://dx.doi.org/10.1037/0033-295X. 84.4.327

Zdyb, M. i Sieradzka, M. (2016). Ustawa o zwalczaniu nieuczciwej konkurencji. Warszawa: Wolters Kluwer. 